\title{
Effects of Strain Type and Water Quality on Soil-Associated Escherichia coli
}

\author{
Daniel L. Gallagher, Kate Lago, Charles Hagedorn, and Andrea M. Dietrich
}

\begin{abstract}
Escherichia coli strains from gulls, chickens, humans, Canada geese, horses, deer, and swine exhibited nearly 25-fold differences in adhesion to kaolinite particles. Hydrophobicity and zeta potential were not correlated with adhesion. There were significant differences in adhesion patterns between avian strains and most mammalian strains, while there were no differences in adhesion patterns between domestic animal strains and wild strains, or between ruminant and non-ruminant mammals. Selected strains exhibited varying responses to changes in $\mathrm{pH}$, sorbent type, ionic strength, and generational cell age. The results indicate that adhesion by different strains under varying environmental conditions is more variable than previously recognized and that sediment-adhered bacteria can represent a significant population. Such wide variation in adhesion behavior could affect the assessment of bacterial contamination in receiving waters, and has implications for field sampling techniques, laboratory culture conditions, and experimental design of water quality projects, including TMDL protocols.
\end{abstract}

Index Terms-E. coli, fecal coliforms, water pollution, bacterial adhesion, microbial source tracking.

\section{INTRODUCTION}

Elevated levels of Escherichia coli (E. coli) are correlated with increased risk of disease, yet fecal contamination continues to be an increasing problem in the United States and worldwide [1]. The presence of E. coli is used as an indicator of fecal contamination for all types of water supplies, especially with freshwaters [2]. Sources of contamination include surface run-off from agricultural fields and impervious surfaces, concentrated animal feeding operations, failing septic systems, raw sewage, wildlife/birds, and domestic pets [3]-[5]. Human fecal contamination may also indicate the presence of other human pathogens such as Salmonella, hepatitis A and the Norwalk virus. Farm animals frequently carry and shed E. coli O157:H7, which can be fatal to humans in doses as low as 50 cells [6].

However, direct fecal input is not always adequate enough to explain the often widespread and consistent occurrence of E. coli in streams [7]. Once fecal matter enters the water, most of the bacteria attach to particles where they are protected from solar radiation and direct predation from

Manuscript received December 10, 2012; revised January 14, 2013.

D. L. Gallagher, K. Lago and A. M. Dietrich are with the Department of Civil and Environmental Engineering, Virginia Tech, Blacksburg VA 24061-0246 (e-mail: dang@vt.edu; kblago6@hotmail.com; andread@vt.edu)

C. Hagedorn is with the Department of Crop and Soil Environmental Sciences, Virginia Tech, Blacksburg VA 24061 (email: chagedor@vt.edu). protozoa is lessened [8]. Particle-associated E. coli may eventually settle to the bottom and subsequently reproduce [9]. Fine soil particles and high organic matter content may increase survival because $E$. coli can catabolize the organic matter associated with smaller particles [10]. Bacteria in the sediment can be resuspended, creating the potential for elevated levels of $E$. coli in the water column for extended periods of time even when no new source of contamination is present or obvious [11]-[14].

An understanding of the fate and transport processes affecting E. coli is critical in meeting environmental regulations and in controlling their presence in waterways. The USEPA Clean Water Act of 1977 allows no more than 100 colony-forming units (cfu) $/ 100 \mathrm{~mL}$ of fecal coliforms in a water body; exceeding these limits may result in closing of shellfish beds for harvesting and prohibition of swimming. The USEPA Total Maximum Daily Load (TMDL) program is designed to control nonpoint source pollution including $E$. coli. The TMDL limit is a geometric mean concentration of $126 \mathrm{cfu} / 100 \mathrm{~mL}$ for $E$. coli, and waters exceeding this limit are considered impaired. Over 400 stream and river segments in Virginia are listed as impaired because of elevated fecal coliform concentrations [15].

Determining the sources of fecal pollution is a necessary first step in developing appropriate remediation strategies. Microbial source tracking (MST) can identify bacterial source loadings to water bodies so they may be reduced or eliminated [16]-[18]. For MST to work most effectively, an extensive library of host-origin isolates from the watershed must be developed. One of the drawbacks of MST is that discrepancies sometimes occur between the numbers and types of bacteria isolated from water samples and the estimated animal population densities within the watershed. Standard methods for water sampling are to collect grab samples from the water column. No sampling of sediments is either done or required by the TMDL program. If $E$. coli is capable of adhering to particles and settling out of the water column, then the presence of sediment-based E. coli populations can serve as a recharge source for the water column and confound monitoring results.

The overall goal of this research was to evaluate the effect of $E$. coli strain and water quality on adhesion to particles. The specific objectives were to: determine the extent of adhesion of different strains of $E$. coli to kaolinite under controlled water quality conditions; determine if changes in water quality or soil type impacted the extent of adhesion; determine if adhesion varied with generational age of cells; and determine if cell surface hydrophobicity or charge correlated with adhesion. 


\section{MATERIALS AND METHODS}

\section{A. Stock Cultures of E. coli Strains}

The E. coli strains included: human (Homo sapiens, HSX 220801-06), horse (Equus caballus, ECX 120901-B5), chicken (Gallus gallus, GAX 230801-45), swine (Sus scrofa, JSX 210801-18), deer (Odocoileus virginianus, 44-10), Herring gull (Larus argentatus, strains B and C), Canada goose (Branta canadensis, 45-4), beef cow (Bos taurus, WH8 1039A) and dairy cow (Bos taurus, DH2 1030A). All cultures were isolated and maintained in the laboratory of Dr. Charles Hagedorn (Virginia Tech). The cultures used were third transfers from field isolated strains and were stored in $30 \%$ glycerol solutions at $-70^{\circ} \mathrm{C}$ [19]. All experiments were performed by inoculating these cultures into Tryptic soy broth (Difco) and growing colonies on Trypic soy agar (Difco). No additional generations were used unless otherwise stated.

\section{B. Solution and Sorbent Preparation}

Two $10 \mathrm{~L}$ bottles of dechlorinated tap water (New River water processed through a conventional water treatment plant) were autoclaved and used over the course of the research. This water contained $0.8 \mathrm{mg} / \mathrm{L}$ total organic carbon. All $\mathrm{CaCl}_{2}$ and $\mathrm{NaCl}$ incubation solutions were prepared using this water and all solutions were autoclaved prior to use. A Nanopure ${ }^{\circledR}$ system was used to generate reagent-grade water.

Fisher Scientific Lab grade Colloidal Kaolinite clay $\left(\mathrm{Al}_{2}(\mathrm{OH})_{4} \mathrm{Si}_{2} \mathrm{O}_{5}\right)$ was used. This kaolinite had particle sizes of $0.1-5.0 \mu \mathrm{m}$, surface area of $5-20 \mathrm{~m}^{2} / \mathrm{g}$ and cation exchange capacity of 3-15 meq/100 g. The clay was hydrated by soaking $2.0 \mathrm{~g}$ per $10 \mathrm{~mL}$ reagent water for three days. This slurry was centrifuged and the supernatant decanted [20]. The kaolinite was not autoclaved because this may have released nutrients that could stimulate the growth of the bacteria [21].

Sandy loam soil was obtained from the top $30 \mathrm{~cm}$ of an agriculture area in coastal Virginia. The sandy loam consisted of $70 \%$ sand, $24 \%$ silt, and $6 \%$ clay with a $\mathrm{pH}$ of 6.5 and $1.2 \%$ organic matter. The sandy loam was allowed to air dry but was not autoclaved. Control experiments using the same methodology as described below but without added bacterial indicated that the soil contained a few indigenous $E$. coli (40-100 cfu/mL). However, these counts were considerably less than the $10^{6}-10^{7} \mathrm{cfu} / \mathrm{mL}$ used in the experiments. The sand was commercial grade sand box material purchased at a local home supply store. It was heated in a $550^{\circ} \mathrm{C}$ furnace to remove all organics (and any resident $E$. coli) and stored in a desiccator.

\section{Working Cultures of E. coli}

All materials were autoclaved prior to use. A volume of $100 \mathrm{uL}$ of an individual $E$. coli strain was grown in $150 \mathrm{~mL}$ of Tryptic soy broth at $37^{\circ} \mathrm{C}$ until percent transmittance at 640 $\mathrm{nm}$ reached $\approx 90 \% \mathrm{~T}$. The growth rate of the ten $E$. coli strains was fairly consistently as individual strains required between 2 and 3 hours to reach $90 \% \mathrm{~T}$. Then $10 \mathrm{~mL}$ of culture was placed into each of 12 tubes and centrifuged for 15 minutes at $4700 \mathrm{rpm}$. The supernatant was decanted, and the cells were washed twice with $10 \mathrm{~mL}$ of incubation solution (dechlorinated tap water with appropriate salt or $\mathrm{pH}$ adjustment as described for each experiment) and vortexed to re-suspend. After the second washing, the cells were re-suspended in incubation solution [22], [23]. Six replicate plates were prepared (spread-plate protocol) and counts recorded after incubation. Generally, the number of E. coli in these working cultures was $10^{6}$ to $10^{7}$ cells $/ \mathrm{mL}$.

\section{Adhesion of E. coli}

Individual experiments were conducted on each strain to determine adhesion. Six control tubes contained no soil, and the six treatment tubes received $2.0 \mathrm{~g}$ of soil. The $\mathrm{pH}$ with kaolinite was approximately $6.5+/-0.1$ and all tubes were adjusted to this $\mathrm{pH}$ if significantly different. All tubes were incubated for $20 \mathrm{~min}$ at $25^{\circ} \mathrm{C}$ with a gentle rolling motion to keep the soil suspended. After incubation, all twelve tubes were centrifuged for $15 \mathrm{sec}$ at $4700 \mathrm{rpm}$ to separate the sorbent from the cells in solution [2], [23], [24]. The supernatant was serially diluted (typically $10^{-2}$ to $10^{-4}$ for goose and $10^{-5}$ to $10^{-6}$ for beef) and $1.0 \mathrm{~mL}$ was spread-plated to count the bacteria. The plates were incubated at $25^{\circ} \mathrm{C}$ for $24 \mathrm{hr}$.

Control experiments with kaolinite indicated that approximately $0.001 \mathrm{~g}$ of the $2.0 \mathrm{~g}$ of clay remained in the supernatant, thus $>99 \%$ of the kaolinite was remove by a 15 sec centrifugation. Control experiments (no kaolinite) indicated that the 15 second centrifugation removed less than $4 \%$ of the bacteria from the supernatant.

Percent adhesion and adhered bacterial concentrations were used to evaluate the degree of adhesion. The number of bacteria adhered was calculated as the difference between the number of bacteria initially in solution prior to adding sorbent and the number of bacteria in solution after incubation for 20 minutes with sorbent. The control tubes indicated that reproduction was not significant in the 20 minute incubation period. The adhered bacterial concentration was obtained by dividing the number of bacteria adhered by the mass of sorbent (reported as cfu/g).

\section{E. Effect of $\mathrm{pH}$, Salt Type, and Soil}

To determine the effect of $\mathrm{pH}$, the $\mathrm{pH}$ of the $3.5 \mathrm{mM} \mathrm{CaCl}_{2}$ incubation solution containing $10 \mathrm{~mL}$ of $E$. coli suspension and $2.0 \mathrm{~g}$ kaolinite was adjusted to either $\mathrm{pH} 6.0$ or 7.0 with the addition of microliter amounts of $0.1 \mathrm{~N} \mathrm{NaOH}$ or $0.1 \mathrm{~N}$ $\mathrm{HCl}$. Adhesion experiments were performed as previously stated. $\mathrm{pH}$ experiments were performed using the goose and beef $E$. coli strains.

Receiving waters include fresh, estuarine, and salt waters. Adhesion as a function of salt concentration was investigated in $\mathrm{pH} 6.5$ incubation solutions with 70.0, 14.0, 7.0, and 3.5 $\mathrm{mM} \mathrm{CaCl}_{2}$ (ionic strength $0.42,0.084,0.042$, and $0.021 \mathrm{mM}$ respectively). Experiments were performed as described for the kaolinite. For soil evaluation, a mass of $2.0 \mathrm{~g}$ of sand or sandy loam was added to $10.0 \mathrm{~mL}$ of incubating solution with either $70.0 \mathrm{mM} \mathrm{CaCl}_{2}$ or $150.0 \mathrm{mM} \mathrm{NaCl}$.

\section{F. Isotherm Development}

Isotherm studies were conducted on the goose and beef strains by altering sorbent mass while maintaining initial bacterial concentrations at a constant. For the beef strain, 6.0, 
$4.0,3.0,2.0$ and $0.5 \mathrm{~g}$ of clay were added to $10 \mathrm{~mL}$ of incubation solution. For the goose strain, 2.00, 0.50, 0.20, $0.10,0.05$ and $0.02 \mathrm{~g}$ of clay were added to $10 \mathrm{~mL}$ of incubation solution. Different soil concentrations were necessary because of the difference in $E$. coli adhesions between the two strains. Isotherm experiments were performed using $3.5 \mathrm{mM} \mathrm{CaCl}_{2}$ as the incubation solution with the $\mathrm{pH}$ adjusted to 6.5 by the addition of microliter amounts of $0.1 \mathrm{~N} \mathrm{NaOH}$ or $0.1 \mathrm{~N} \mathrm{HCl}$. Adjustment was necessary because the varying amounts of kaolinite in the 10 $\mathrm{mL}$ volume altered the $\mathrm{pH}$ from 7.29 to 6.27 .

\section{G. Generational Experiments}

A generational experiment was performed to determine if adhesion changed over time as a function of the age of the $E$. coli strain. The adhesion to kaolinite was determined approximately every 50 generations up to 300 generations. For example, based on the growth curve data, the doubling time was determined to be 40 minutes for the beef strain. Based on this doubling time, each 50 generations would occur roughly every 33 hours. To maintain the strains in exponential growth, a new flask was inoculated approximately every 5 hours $(\% \mathrm{~T}=46)$. Adhesion experiments were performed as previously described.

\section{H. Cell Surface Properties}

The zeta potential was measured for each strain using a Malvern Zetasizer $3000 \mathrm{HS}$ and individual E. coli grown to approximately $85-90 \% \mathrm{~T}$ and resuspended in $3.5 \mathrm{mM} \mathrm{CaCl}$ incubation solution. Hydrophobicities of the individual $E$. coli strains were measured using the method of [25]. An aqueous solution of the individual $E$. coli strain grown in 3.5 $\mathrm{mM} \mathrm{CaCl} 2$ incubation solution was partitioned between the aqueous incubation solution and hexadecane. The absorbance of the aqueous suspensions was measured at 640 $\mathrm{nm}$ wavelength before and after partitioning. Hydrophobic cells will enter into the hexadecane and reduce the turbidity of the aqueous suspension.

\section{RESULTS}

\section{A. Comparison of Adhesion for Individual E. coli Strains}

When individual strains of $E$. coli were incubated under conditions of approximately $10^{6}$ cells $/ \mathrm{mL}$ in $2.0 \mathrm{~g}$ kaolinite/10 $\mathrm{mL}$ incubation solution, $\mathrm{pH} 6.5$, the results indicated that there was significant variation, over 25 -fold, in the cellular adhesion to clay (Fig. 1). Based on adhesion, the strains could be divided into three groups with gulls being highly adhered, chicken, human, goose and horse moderately adhered, and both cow strains, pig and deer with lower adhesion. A nonparametric Kruskal-Wallis multiple comparison found that adhesion of the gull strains were significantly different from adhesion of each of the dairy cow, pig, deer and dairy cow strains $(\alpha=0.05)$. Thus in general, the strains from avian species were more highly adhered than those from mammalian species, and there was no trend between ruminant and non-ruminant mammals. No trend occurred between domesticated and wild animals.

Based on the adhesion results, the beef cow (lowest adhesion) and goose strains (moderately high adhesion) were selected for additional testing because of their different adhesion response and environmental significance as sources of fecal pollution in water.

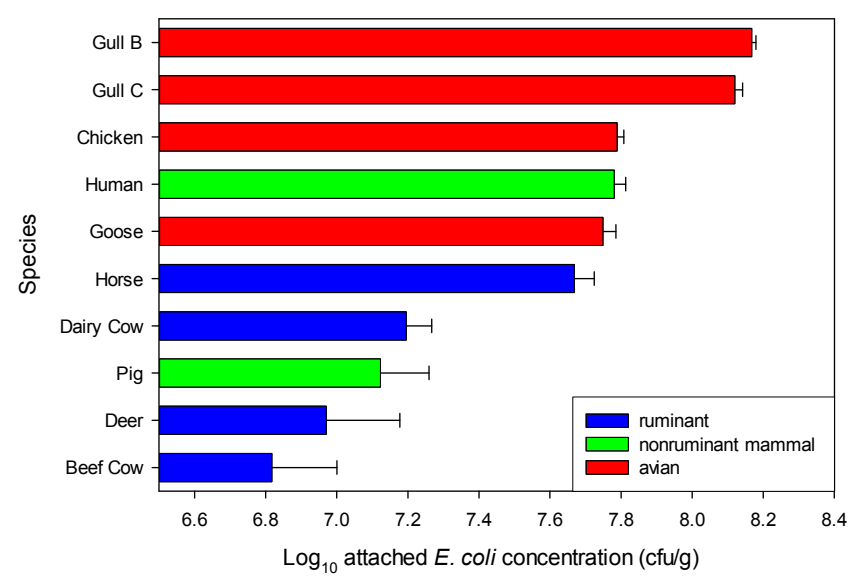

Fig. 1. Adhesion of various strains of $E$. coli onto kaolinite ( $\bar{x} \pm$ std error, $\log$ scale, $n=6)$.

\section{B. Effect of $p H$, Salt Type, and Sorbent}

Adhesion of the goose and beef strains were studied at $\mathrm{pH}$ $6.0,6.5$ or 7.0 (Fig. 2). The goose strain showed a 7 -fold decrease in adhesion as $\mathrm{pH}$ increased from 6 to 7 , with little variability. The beef strain, however, showed very little change in adhesion at any of the $\mathrm{pH}$ levels studied, with much greater variability.

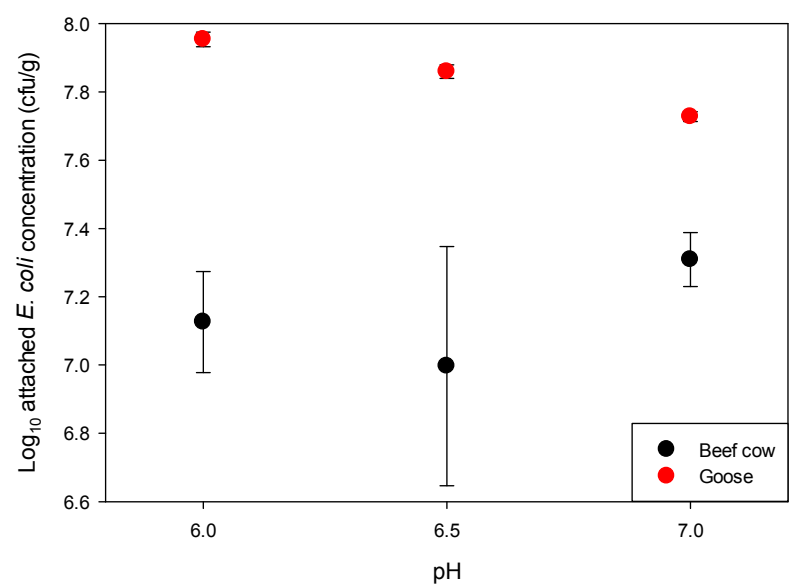

Fig. 2. Impact of $\mathrm{pH}$ on adhesion of goose and beef $E$. coli to kaolinite. $(\bar{x} \pm$ std error, log scale, $\mathrm{n}=6)$.

The ionic strength and calcium concentration had little impact on the adhesion of goose-derived $E$. coli to kaolinite, but increasing the calcium resulted in a 10 -fold increase in adhesion of the beef strain (Fig. 3).

Three sorbents were compared using both calcium and sodium solutions (Fig. 4). Both the beef and goose strains adhered best to the negatively charged kaolinite particles, and poorest to the silica based sand particles. Adhesion was more sensitive to different media with sodium as the cation than with calcium.

\section{Isotherms}

For the goose strain, increasing kaolinite from 0.02 to 2 $\mathrm{g} / 10 \mathrm{~mL}$ resulted in a 100 -fold increase in the adhered 
concentration (Fig. 5). A possible maximum adhered concentration of $8 \times 10^{8} \mathrm{cfu} / \mathrm{g}$ occurred at aqueous equilibrium concentrations of $10^{5} \mathrm{cfu} / \mathrm{mL}$ or higher. There was no similar pattern found for the beef strain where the adhered concentration appeared to remain at about $1 \times 10^{7}$ $\mathrm{cfu} / \mathrm{g}$ independent of the equilibrium concentration.

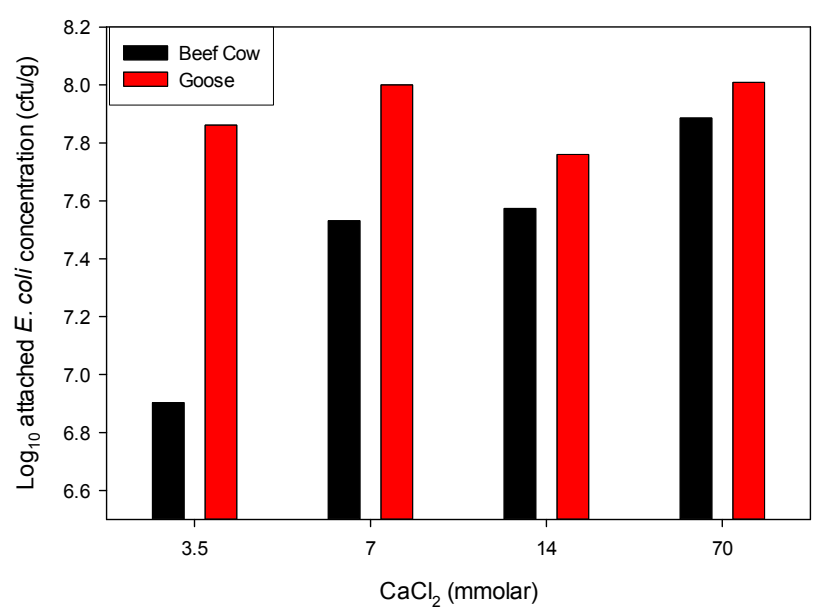

Fig. 3. Impact of calcium chloride on adhesion to kaolinite for beef and goose E. coli strains.

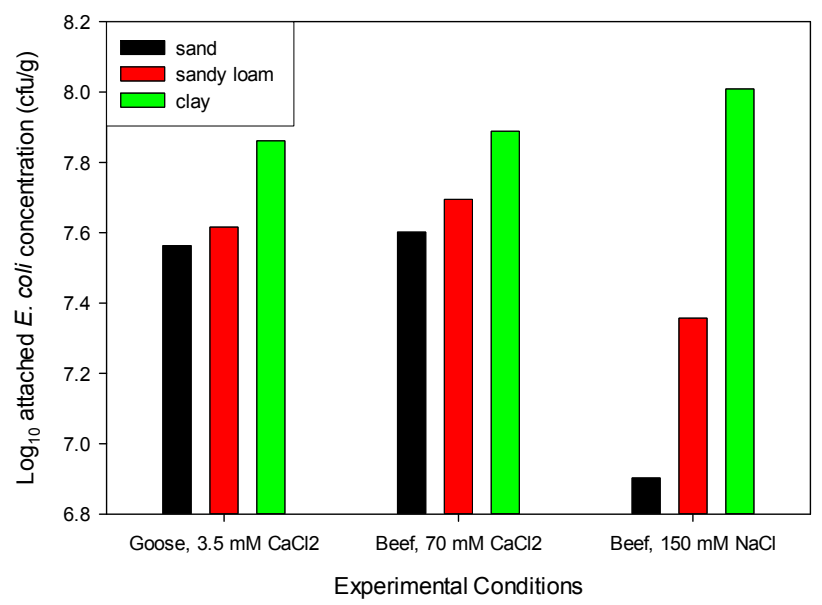

Fig. 4. Impact of sorbent type on adhesion of E. coli.

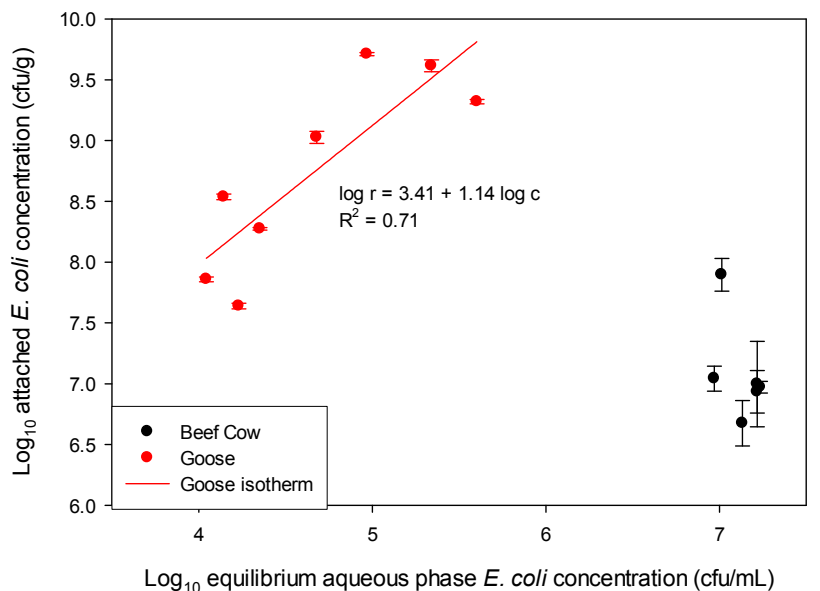

Fig. 5. Isotherms for goose and beef strains; concentration of kaolinite was varied. ( $\bar{x} \pm$ std error, $\log$ scale, $\mathrm{n}=6$ ).

\section{Generational Studies}

Two strains of E. coli were grown and tested over 300 generations to determine the impact of cell reproduction on adhesion (Fig. 6). The goose strain was relatively constant across 300 generations. The beef strain, however, showed a rapid increase in adhesion potential as the population aged from the initial culture to fifty generations and adhered as well as the goose strain after 50 generations.

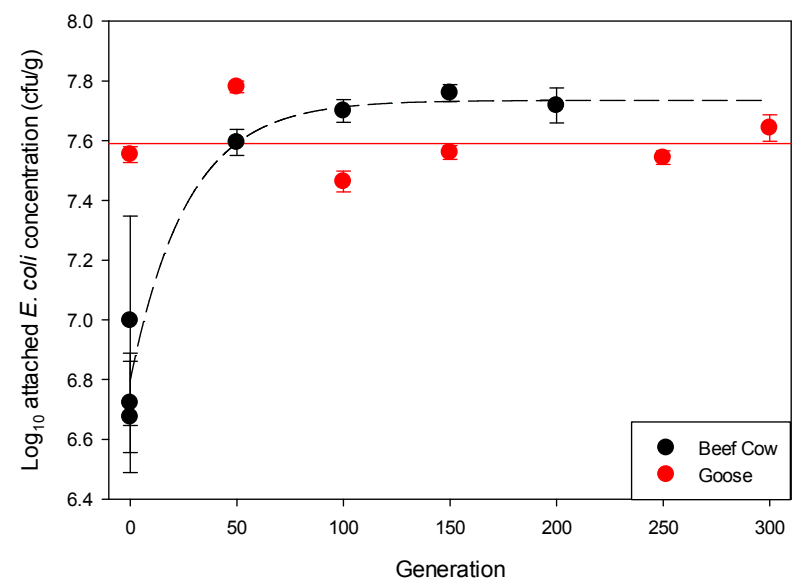

Fig. 6. Results of generational studies for beef and goose E. coli strains $(\bar{x} \pm$ std error, log scale, $\mathrm{n}=6)$.

\section{E. Correlation with Cell Surface Properties}

Cell surface charge may play a role in bacterial adhesion. Values of the zeta potential (Table I) varied from -14 to -20 $\mathrm{mV}$, with the exception of the beef strain which was $-6.8 \mathrm{mV}$. No trend was detected between adhesion to kaolinite and cell surface charge $\left(\mathrm{R}^{2}=0.07\right)$.

Cell surface hydrophobicity is another parameter associated with adhesion. The strains of $E$. coli used in these experiments were generally not hydrophobic (Table I) and hydrophobicity did not correlate with adhesion $\left(\mathrm{R}^{2}=0.02\right)$. For the goose strain, the hydrophobicity changed with generation, but adhesion did not. Conversely for the beef strain, the hydrophobicity did not change with generation but adhesion increased. This finding further confirms that hydrophobicity may not be an appropriate surrogate for adhesion.

TABLE I: ZETA POTENTIAL AND \% HYDROPHOBICITY FOR VARIOUS

\begin{tabular}{lccc}
\multicolumn{1}{c}{ Strain } & $\begin{array}{c}\text { Zeta } \\
\text { Potential }\end{array}$ & $\begin{array}{c}\text { \% } \\
\text { Hydrophobicity }\end{array}$ & $\begin{array}{c}\text { Log10 attached } \\
\text { E. coli }(\mathbf{c f u} / \mathbf{g})\end{array}$ \\
\hline Gull B & -19.4 & 6.3 & 8.17 \\
Gull C & -14.1 & 19.4 & 8.12 \\
Goose & -20.9 & 2.2 & 7.86 \\
Goose (300 & ND & 63.0 & 7.65 \\
generations) & -18.9 & 2.4 & 7.79 \\
Chicken & -17.0 & 2.1 & 6.90 \\
Beef Cow & ND & 2.6 & 7.74 \\
Beef (200 & -6.8 & 10.9 & 7.22 \\
generations) & -19.0 & 2.2 & 7.69 \\
Dairy Cow & -17.5 & 1.3 & 7.06 \\
Horse & -20.0 & 7.4 & 7.79 \\
Deer & -19.9 & 3.6 & 7.22 \\
Human & & & \\
Pig & & & \\
\hline \hline
\end{tabular}

* not determined 


\section{Discussion}

Limited research has been conducted to compare strain-specific adhesion of E. coli [26]. This research found that $E$. coli strains from various sources exhibited differences in adhesion to kaolinite under the same water quality conditions, but this adhesion was not correlated with hydrophobicity or zeta potential. Selected strains exhibited varying responses to changes in $\mathrm{pH}$, sorbent type, ionic strength, and generational cell age. Uses of antibiotics in agricultural animals could be responsible for the expression of certain resistance characteristics in E. coli strains [27]-[29], but our results found no differences between adhesion patterns in domestic animal strains likely exposed to antibiotics and wild strains that likely were not. Nor were different adhesion patterns found between ruminant and non-ruminant mammals, although this finding does not preclude diet having an effect as has been previously shown for cow, deer and sheep [30]-[32].

When the $\mathrm{pH}$ was increased from 6.0 to 7.0 , the goose strain showed 7-fold decrease in adhesion and little variability. Conversely, the beef strain showed minimal change in adhesion due to $\mathrm{pH}$ changes and was also highly variable.

Researchers evaluated $E$. coli adhesion to beef muscle tissue over a wider $\mathrm{pH}$ range (4 to 10 ) and found marked differences between two strains [25]. They concluded that the influence of $\mathrm{pH}$ was likely due to changes in the beef muscle substratum. Our results indicate similar findings in that one strain is affected by changes in $\mathrm{pH}$ but not the other, but since all other conditions remained constant, it seems likely that $\mathrm{pH}$ effects were strain specific and may impact cell surface structures to alter ability to adhere to certain types of particles.

When altering the ionic strength and concentration of divalent calcium ion of the incubating medium, the well-adhered goose strain showed little variability with concentrations ranging from $3.5 \mathrm{mM}$ to $70 \mathrm{mM} \mathrm{CaCl}_{2}$. The poorly-adhered beef strain increased 10 -fold when calcium chloride levels were similarly increased. This is contradictory to the results of [25], who reported that increasing ionic strength of the monovalent sodium-based phosphate buffer from 1.5 to $150 \mathrm{mM}$ decreased the number of $E$. coli cells strongly adhering to beef muscle by about 10 -fold. Other researchers found ionic strength had little impact on adhesion of Salmonella to poultry tissue [33]. The influence of ionic strength may be explained by interaction of electrostatic charge on the bacterial surfaces. At a high salt concentration, the outer wall layers of bacteria may be altered and structures involved in adhesion may be denatured or released into the medium. Alternatively, multivalent cations may act as bridging agents between cells and substrate. Lastly, an individual strain could adhere to muscle or tissue differently than how it adheres to clay-based materials, making such comparisons less useful.

The sorbent type also has an impact on adhesion. The sandy loam had less adhesion than the kaolinite, and sand had the least. There was less variability in adhesion with $70 \mathrm{mM}$ $\mathrm{CaCl}_{2}$ than with $150 \mathrm{mM} \mathrm{NaCl}$. This could be due to the divalency of the calcium reducing the repulsive force between the negatively charged kaolinite and the negatively charged bacteria. The increased adhesion to clay was shown in other studies, and attributed to increased organic matter associated with clay, the particle surface charge and increased surface area [10], [34]. The kaolinite used for our experiments lacked organic matter, but surface charge and surface area would be similar. Studies suggest that E. coli survive longer in sediments higher in clay (at least 25\%) than in sand. This increased survival has primarily to do with particle size, but also increased organic matter and nutrients [34], [35].

Subculturing strains in the lab has been suggested as a method by which strains might adapt to different environmental conditions [26]. For the goose strain there was relatively constant adhesion from the original 3rd generation culture obtained from the field (0 generation) through 300 generations. For the beef strain there was an initial increase from the original culture to the 50 generation, after which adhesion became relatively constant, and interestingly, was very similar to the goose. These results suggest a strain-specific impact for subculturing as related to adhesion. Further work is needed to explain these adaptations.

Initial bacterial concentration may also impact the amount of adhesion that occurs. Research has found that increased cells in the initial suspension resulted in more cells adhering to beef muscle [25]. Although we were comparing adhesion to kaolinite, similar results were found for only the goose strain, but not the beef strain.

Surface hydrophobicity generally coincides with increased adhesion to minerals, but so does composition, surface charge, hydrophobicity and surface roughness of the sediment [36]. All strains used in these experiments exhibited a negative cell surface charge ranging from -6.8 to $-20.9 \mathrm{mV}$. However, ionic strength of a medium serves to decrease the repulsive forces between the cell surface charge and the clay's negative surface charge [37]. There was no relationship between the surface charge (zeta potential) or hydrophobicity and amount of adhesion that occurred to kaolinite, and this conclusion has been supported in other research [25]. While the methods and results are consistent with [25], limitations existing in applying surface hydrophobicity and zeta potential tests to soft biological surfaces. For example, cell surface and structural features change depending on the ionic strength, $\mathrm{pH}$ and other environmental conditions. These surface features could impact the hydrodynamic mobility and therefore the zeta potential results. Further research is warranted.

The results suggest that a great deal of variability exists for E. coli adhesion to sediment based on environmental conditions and strain. USEPA requires only grab water samples be tested for monitoring water quality, but every time the water is stirred, adhered bacteria can be resuspended and transported downstream and into terminal reservoirs [36]. For microbial source tracking to be fully utilized, the variation in adhesion of different $E$. coli strains will need to be considered, as will the impact of sediment-based populations on water quality studies and the TMDL program [38].

The results also suggest that simple planktonic-phase modeling for TMDLs may be inadequate to explain E. coli fate and transport. The models typically consider only the dissolved phase bacteria and assume a $1^{\text {st }}$ order die-off rate. 
Our results, and those of others [21], [39], [40], demonstrate that sediment-adhered bacteria can represent a significant population. These adhered bacteria survive and may reproduce and desorb [41], thus invalidating many of the assumed parameters used in the typical TMDL approach.

\section{Conclusions}

Considerable differences for adhesion of $E$. coli strains from a variety of host animals were observed across water quality parameters, sorbent types, sorbent concentrations, and culturing conditions. The results imply that microbial source tracking should probably be a composite of not only the bacterial source animal, but also the fate and transport mechanisms of different host-origin strains in the watershed. It appears that adhesion by different strains under varying environmental conditions is more individualistic than previously recognized. Such wide variation in adhesion behavior could significantly affect the assessment of bacterial contamination in receiving waters, and has important implications for field sampling techniques, laboratory culture conditions, and experimental design of water quality projects including TMDL protocols.

\section{ACKNOWLEDGEMENT}

This research was partially funded by the Edna Bailey Sussman Foundation and the Virginia Water Resources Research Center. Appreciation is expressed to Mrs. Sue Herbein for maintaining and providing the cultures.

\section{REFERENCES}

[1] A. Maule, "Survival of verocytotoxigenic Escherchia coli 0157 in soil, water and on surfaces," J. Appl. Microbiol. Symposium Supplement, vol. 88, pp. 71S-78S, 2000.

[2] D. Francy and R. A. Darner, "Comparison of methods for determining Escherichia coli concentrations in coastal waters," Water Research, vol. 34 , no. 10, pp. 2770-2778, 2000.

[3] R. T. Bannerman, D. W. Owens, R.B. Dodds, and N. J. Hornewer, "Sources of pollutants in Wisconsin storm water," Water Sci. Technol., vol. 28 no. 3-5, pp. 241-259, 1993.

[4] M. Hinton and V. M. Allen, "Some observations on the ecology of Escherichia coli isolated from healthy farm animals." In: Coliforms and E. coli Problem or Solution?" D. Kay and C. Fricker (eds), The Royal Society of Chemistry, Cambridge, pp. 54-60, 1995.

[5] R. Oshiro and R. Fujioka, "Sand, soil, and pigeon droppings: sources of indicator bacteria in the waters of Hanauma Bay, Oahu, Hawaii," Water Sci. Technol. ,vol. 31, no. 5-6, pp. 251-254, 1995.

[6] P. E. Dombek, L. K. Johnson, S. T. Zimmerley, and M. J. Sadowsky, "Use of repetitive DNA sequences and the PCR to differentiate Escherichia coli from human and animal sources," Appl. Environ. Microbiol. vol. 66, no. 6, pp. 2572-2577, 2000.

[7] M. Byappanahalli, M. Fowler, D. Shively and R. Whitman, "Ubiquity and persistence of Escherichia coli in a midwestern coastal stream," Appl. Environ. Microbiol. vol. 69, no. 8, pp. 4549-4555, 2008.

[8] M. Pommepuy, J. F. Guillaud, E. Dupray, A. Derrien, F. LeGuyader and M Cormier, "Enteric bacterial survival factors," Water Sci. Technol., vol. 25, no. 12, pp. 93-103, 1992.

[9] Y. Henis, K. R. Gurijala and M. Alexander, "Factors involved in multiplication and survival of Escherichia coli in lake water," Microbial Ecology, vol. 17, pp. 171-180, 1989.

[10] B. M. Sherer, J. R. Miner, J. A. Moore and J. C. Buckhouse, "Indicator bacterial survival in stream sediment." J. Environ. Quality, vol. 21, pp. 591-595, 1992
[11] G. R. Stephenson and R. C. Rychert, "Bottom sediment: a reservoir of Escherichia coli in rangeland streams," J. Range Management, vol. 35, no. 1 , pp. 119-123, 1982.

[12] J. E. Schillinger and J. J. Gannon, "Bacterial adsorption and suspended particles in urban stormwater," J. Water Pollution Control Federation, vol. 57, pp. 384-389, 1985.

[13] C. M. Davies, J. A. Long, M. Donald.and N. J. Ashbolt, "Survival of fecal microorganisms in marine and freshwater sediment," Appl. Environ. Microbiol., vol. 61, no. 5, pp. 1888-1896, 1995.

[14] R. L. Whitman and M. B. Nevers, "Foreshore sand as a source of Escherichia coli in nearshore water of a Lake Michigan beach," Appl. Environ. Microbiol. vol. 69, no. 9, pp. 5555-5562, 2003.

[15] K. E. Hyer, and D. L. Moyer, "Enhancing fecal coliform Total Maximum Daily Load models through bacterial source tracking," $J$. Amer. Water Resources Assoc., vol. 40, no. 6, pp. 1511-1526, 2004.

[16] C. Hagedorn, S. A. Robinson, J. R. Filtz, S. M. Grubbs, T. A. Angier and R. B. Reneau, Jr., "Determining sources of fecal pollution in a rural Virginia watershed with antibiotic resistance patterns in the fecal streptococci," Appl. Environ. Microbiol,. vol. 65, pp. 5522-5531.

[17] C. A. Carson, B. L. Shear, M. R. Ellersieck and A. Asfaw, "Identification of fecal Escherichia coli from humans and animals by ribotyping," Appl. Environ. Microbiol., vol. 67, no. 4, pp. 1503-1507, 2001.

[18] J. B. Crozier, and H. Weber, "Identifying sources of fecal pollution in the Roanoke River, Roanoke County, Virginia," Virginia Journal of Science, vol. 53, no. 3, pp. 157-165, 2002.

[19] V. J. Harwood, B. Wiggins, C. Hagedorn, R. D. Ellender, J. Gooch, J. Kern, M. Samadpour, A. H. Chapman, and B. J. Robinson, "Phenotypic library-based microbial source tracking methods: efficacy in the California collaborative study," J. Water \& Health, vol. 1, no. 4, pp. 153-156, 2003.

[20] Y. H. An and R. J. Friedman, Handbook of Bacterial Adhesion, Principles and Methods. NJ: Humana Press, 2000.

[21] C. P. Gerba, and J. S. McLeod, "Effect of sediments on the survival of Escherichia coli in marine waters," Appl. Environ. Microbiol, vol. 32, pp. 114-120, 1976

[22] M. M. Roper and K. C. Marshall, "Modification of the interaction between Escherchia coli and bacteriophage in saline sediment," Microbial Ecology, vol. 1, pp. 1-13, 1974.

[23] F. Huysman and W. Verstraete, "Water-facilitated transport of bacteria in unsaturated soil columns: influence of cell surface hydrophobicity and soil properties," Soil Biol. Biochem., vol. 25, no. 1, pp. 83-90, 1993.

[24] S. Dukan, Y. Levi and D. Touati, "Recovery of culturability of an HOCl- stressed population of Escherchia coli after incubation in phosphate buffer: resuscitation or regrowth," Appl. Environ. Microbiol. ,vol. 63, no. 11, pp. 4204-4209, 1997.

[25] J. Li, and L. A. McLandsborough, "The effects of the surface charge and hydrophobicity of $E$. coli on its adhesion to beef muscle." Internat. J. Food Microbiol., vol. 53, no. 2-3, pp. 185-193, 1999.

[26] D. P. Bakker, B. R. Postmus, H. J. Buscher and H.C. van der Mei, "Bacterial strains isolated from different niches can exhibit different patterns of adhesion to substrata." Appl. Environ. Microbiol., vol. 70, pp. 3758-376, 2004.

[27] J. R. Johnson, A. L. Still, P. Delavari, A. C. Murray, M. Kuskowski and W. Gaastra, "Phylogenic and pathogenic similarities between E. coli isolates from UTI in dogs and extra intestinal infections in humans," $J$. Infectious Diseases, vol. 183, pp. 897-906, 2001.

[28] A. Bryan, N. Shapir and M. J. Sadowsky, "Frequency and distribution of tetracycline resistance genes in genetically diverse, nonselected, and nonclinical Escherichia coli strains isolated from diverse human and animal sources," Appl. Environ. Microbiol., vol. 70, no. 4, pp. 2503-2507, 2004.

[29] A. R. Khachatryan, D. D. Hancock, T. E. Besser and D. R. Call, "Role of calf-adapted Escherchia coli in maintenance of antimicrobial drug resistance in dairy calves," Appl. Environ. Microbiol., vol. 70, no. 2, pp. 752-757, 2004.

[30] I. T. Kudva, P. G. Hatfield and C. J. Hovde, "Effect of diet on the shedding of Escherchia coli O157:H7 in a sheep model," Appl. Environ. Microbiol., vol. 61, no. 4, pp. 1363-1370, 1995.

[31] P. G. Hartel, J. D. Summer and W. I. Segars, "Deer diet affects ribotype diversity of Escherichia coli for bacterial source tracking," Water Research, vol. 37, no. 13, pp. 3263-3268, 2003.

[32] J. T. LeJeune, T. E. Besser, D. H. Rice, J. L. Berg, R. P. Stillborn and D. D. Hancock, "Longitudinal study of fecal shedding of Escherchia coli O157:H7 in feedlot cattle: predominance and persistence of specific clonal types despite massive cattle population turnover," Appl. Environ. Microbiol., vol. 70, no. 1, pp. 377-384, 2004. 
[33] H. S. Lillard, "Effect of surfactant or changes of ionic strength on the attachment of Salmonella typhimurium to poultry skin and muscle." $J$. Food Science, vol. 53, no. 3, pp. 727-734, 1988.

[34] J. M. Howell, M. S. Coyne and P. L. Cornelius, "Effect of sediment particle size and temperature on fecal bacteria mortality rates and the fecal coliform/fecal streptococci ratio," J. Environ. Quality, vol. 25, pp 1216-1220, 1996.

[35] G. A. Burton Jr., D. Gunnison and G. R. Lanza, "Survival of pathogenic bacteria in various freshwater sediments," Appl. Environ. Microbiol., vol. 53 , no. 4 , pp. $633-638,1986$

[36] T. A. Stenstroem and A. Carlander, "Occurrence and die-off of indicator organisms in the sediment in two constructed wetlands," Water Sci. Technol., vol. 44, no. 11-12, pp. 223-230, 2001.

[37] M. Fletcher, Bacterial Adhesion: Molecular and Ecological Diversity, New York, NY: John Wiley \& Sons, 1996.
[38] P. Beaudeau, N. Tousset, F. Bruchon, A. Lefevre and H. D. Taylor, "In situ measurement and statistical modeling of Escherichia coli decay in small rivers," Water Research, vol. 35, pp. 3168-3178, 2001.

[39] I. Brettar and M. G. Hoefle, "Influence of ecosystematic factors on survival of E. coli after large-scale release into lake water mesocosms," Appl. Environ. Microbiol.,vol. 58 no. 7, pp. 2201-2210, 1992.

[40] H. M. Solo-Gabriele, M. A. Wolfert, T. R. Desmarais and C. J. Palmer. "Source of Escherichia coli in a coastal subtropical environment," Appl. Environ. Microbiol., vol. 66, no. 1, pp. 230-237, 2000.

[41] G. Bogosian , L.E. Sammons, P. J. L. Morris, J. P. O’Neil, M. A. Heitkamp, and D. B. Weber, "Death of the Escherichia coli K-12 strain W3110 in soil and water," Appl. Environ. Microbiol. vol. 62, no. 11, pp. 4114-4120, 1996. 